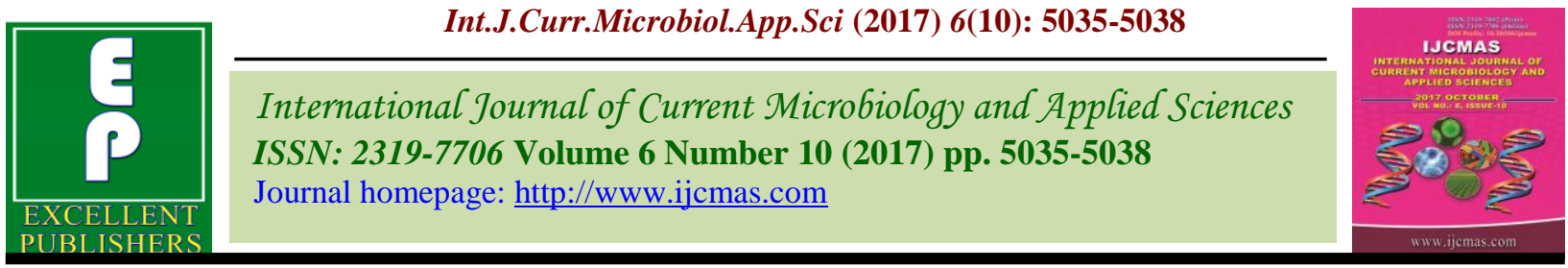

Review Article

https://doi.org/10.20546/ijcmas.2017.610.477

\title{
Interspecies Cloning-A Step towards Conservation of Endangered Species: A Review
}

\author{
Sajad A. Beigh*, Wani A. Ahad, Rumase A. Bhat, Mehrajuddin Reshi, \\ Riaz A. Shah and Neelofar Nabi
}
Faculty of Veterinary Science and Animal Husbandry, Sher-e-Kashmir University of
Agricultural Science and Technology of Kashmir, Shuhama Alusteng, India
*Corresponding author

\begin{tabular}{|c|c|}
\hline & A B S T R A C T \\
\hline Keywords & $\begin{array}{l}\text { Interspecies cloning has a prudent and promising role to be played in future } \\
\text { for conservation of endangered species Many ex-situ conservation }\end{array}$ \\
\hline $\begin{array}{l}\text { Interspecies } \\
\text { cloning, ex-situ } \\
\text { conservation, } \\
\text { endangered }\end{array}$ & $\begin{array}{l}\text { programs employed till date are not enough to tackle the problem of } \\
\text { conservation of endangered species. These programs need to be } \\
\text { supplemented with other innovation techniques like interspecies cloning }\end{array}$ \\
\hline Article Info & international projects have been successful in interspecies cloning of \\
\hline $\begin{array}{l}\text { Accepted: } \\
30 \text { August } 2017 \\
\text { Available Online: } \\
10 \text { October } 2017\end{array}$ & $\begin{array}{l}\text { various endangered animals but it has to be operated at larger global extent. } \\
\text { The technique is at lag phase and we have to bring it on log phase by doing } \\
\text { ample research in field so that it could be standardized at optimum levels in } \\
\text { species of interest that are under focus of conservation. }\end{array}$ \\
\hline
\end{tabular}

\section{Introduction}

Innovations being the raw material for new development and technology have not only served mankind but also other animals which are rare and whom which humans want to have an intimate desire for harmonious coexistence. There are several species of mammals, fishes and birds which are at the verge of extinction. According to reports $25 \%$ of mammals, $34 \%$ of fish species and $11 \%$ of bird species are at the verge of extinction (1).

The efforts to maintain biodiversity via habitat and wildlife conservation are not ample enough for conservation programs and still chances for extinction of rare and endangered vertebrate species remain prudent (3). A series of captive propagation programs are being currently employed in captive animals which are endangered for preserving their genetic diversity. However, these programs have their own drawbacks which include problems with animal husbandry, reproductive failure of animals and restricted physical space (9). With the advancement in assisted reproductive techniques such as artificial insemination, in vitro fertilization, intracytoplasmic sperm injection (ICSI), cryogenics of gametes, oocytes, embryos and embryo transfer have opened new ways for further propagation of endangered species. 


\section{Interspecies Cloning}

Interspecies cloning involves the transfer of a nucleus or cell from one species into the cytoplasm of an enucleated oocyte from another related specie. Once activated, reconstructed oocytes can be cultured in vitro to blastocyst and then transferred in oocyterecipient specie. There are two interspecies cloning technique:

Interspecies somatic cell nuclear transfer (iSCNT)

Interspecies handmade cloning (iHMC)

The aim of both of these techniques is to generate cytoplasts from related specie and then fuse it with the somatic cells of animal which is to be cloned. The difference between these two techniques lies in the generation of oocyte-cytoplast reconstructs. In iSCNT, the cytoplast is generated by ennucleation with the help of ennucleation pipette on micromanipulator keeping zonapellucida intact. In iHMC, the cyoplast of recipient specie is generated by cutting the protrusion cone of IVM oocyte after dissolving the zonapellucida layer.

Many mammalian species have been successfully cloned by iSCNT considering that iSCNT will serve as a pivotal technique in cloning for conservation of endangered mammalian species. The different wild animals which have been cloned by iSCNT are gaur (8), mouflon (10), banteng (12), female gray wolf (7) and male gray wolf (11).

Many studied have shown that it is possible to produce embryos from endangered species by interspecies or intergeneric SCNT. However, in reports few live cloned wild mammals have been produced and embryos of these animals were produced by reconstructing them with donor oocyte of the same specie $(8 ; 10 ; 5 ; 6$;
7). As far as intergeneric SCNT is considered viable off springs have not been produced in any mammalian species. However, with intergeneric cloned embryos pregnancies have been established after transfer in sheep or domestic cat recipient $(4 ; 2 ; 13)$. The multifactorial causes which are responsible for successful development of iSCNT embryos are similar to those reported for intraspecies SCNT which includes source of oocyte cytoplast, cell cycle stage of donor cells, genotype of donor cells and synchronization.

Khaleej times, On May18, 2017, published news that DrNissar and his collagues in Dubi cloned bacterian camel calf by using single humped camel as source of oocytesat the reproductive biotechnology centre in Dubai. Thus it opened the door of success for cloning of double humped camel which are less in number than double humped camels.

\section{Other implications}

Besides, the animals which have low reproductive efficiencies, their reproducing efficiency can be increased by interspecies cloning. Interspecies cloning derived embryonic stem cells can be produced and used for therapeutic purposes. It could be used as a model to study events occurring during early embryonic development.

Interspecies cloning technique may become instrumental in rescuing endangered species in future and possibly reverse extinctions that have already occurred. Various wildlife conservations programs have used captive propagation programs to preserve endangered species in captivity. Limitations such as restricted physical space for animals, problems with animal husbandry and general reproductive failure of the animals have created the need for additional propagation programs. 


\section{Steps in interspecies cloning}

\section{0}

1. Isolation \& culture of Donor Cells from Endangered animal

3.Enucleation of

Oocytes

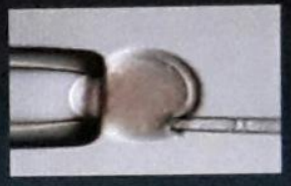

है:

4. Fusion of

donor cells with

Cytoplast

5. Activation of reconstruct

\section{Gestation}

7. Transfer to surrogate
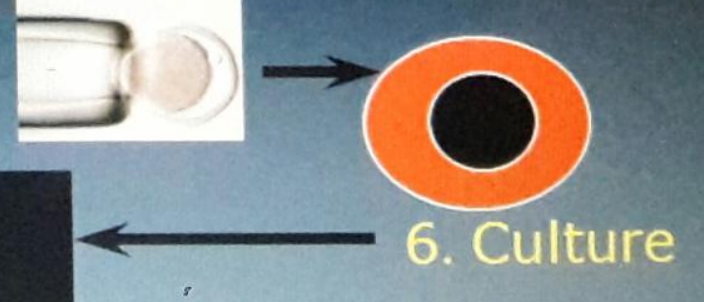
Most ethicists who strongly oppose human cloning see no problem in using the technique to rescue endangered species. Thus, interspecies nuclear transfer technology also creates the possibility for restoring alreadyextinct species from which intact cell lines are available. This highlights the importance of establishing repositories of the cell lines of endangered species, which are imperative to create a 'genetic trust' for future cloning efforts.

\section{References}

1. Alexander, C.P., and porter 2000. Death row. Time 155: 75-78.

2. Chen, D.Y., Wen, D.C., Zhang, Y.P., Sun, Q.Y., Han, Z.M. 2002. Interspecies implantation and mitochondria fate of pandarabbit cloned embryos. Biol. Reprod.67: 637642.

3. Corley-Smith, G. E., and Brandhorst, B.P. 1999. Preservation of endangered species and populations: a role for genome banking, Somatic cell cloning and androgenesis. Mol. Reprod. Dev. 53: 363-367.

4. Dominko, T., Ramalho-Santos J, Chan A, Moreno R, Luetjens C, Simerly C, Hewitson L, Takahashi D, Martinovich C, White J. 1999. Optimization strategies for production of mammalian embryos by nuclear transfer. Cloning, 1: 143-152.

5. Gómez, M.C., Pope, C.E., Giraldo, A., Lyons, L.A., Harris, R. F., King, A. L., Cole, A., Godke, R. A., and Dresser, B. L. 2004. Birth of African wildcat cloned kittens born from domestic cats. Cloning Stem Cells6:247-258.

6. Janssen, D., Edwards M, Koster J, Lanza R, Ryder O. 2004. Postnatal management of cheyptorchidbanteng calves cloned by nuclear transfer utilizing forzen fibroblast cultures and enucleated cow ova. Reprod. Fertil. Dev. 16: 224-224.

7. Kim, M., Jang G, Oh H, Yuda F, Kim H, Hwang W, Hossein M, Kim J, Shin N, Kang S. 2007. Endangered wolves cloned from adult somatic cells. Cloning Stem Cells, 9:130-137.

8. Lanza, R.P., Cibelli JB, Diaz F, Moraes CT, Farin PW, Farin CE, HammerCJ, West MD, Damiani P 2000. Cloning of an endangered species (Bosgaurus) using interspecies nuclear transfer.Cloning 2: 79-90.

9. Lasley, B.L., Loskutoff, N.M., and Anderson, G.B. 1994. The limitations of conventional breeding programs and the need and promise of assisted reproduction in nondomestic species. Theriogenology 41:119-132.

10. Loi, P., Ptak, G., Barboni, B., Fulka, J., Cappai, P., and Clinton, M. 2001. Genetic rescue of an endangered mammal by crossspecies nuclear transfer using post-mortem somatic cells. Nat. Biotechnol. 19: 962-964.

11. Oh, H.J., Kim M. K, Jang G, Kim H. J, Hong S. G, Park J. E, Park K, Park C, Sohn S. H, Kim D. Y, Shin N. S, Lee B. C. 2008. Cloning endangered gray wolves (Canis lupus) from somatic cells collected postmortem. Theriogenology 70: 638-647.

12. Sansinena, M., Hylan D, Hebert K, Denniston R, Godke R. 2005. Banteng (Bosjavanicus) embryos and pregnancies produced by interspecies nuclear transfer. Theriogenology 63: 1081-1091.

13. Yin, X., Lee, Y., Lee, H., Kim, N., Kim, L., Shin, K., and Kong, I. 2006. In vitro production and initiation of pregnancies in inter-genus nuclear transfer embryos derived from leopard cat (Prionailurusbengalensis) nuclei fused with domestic cat (Felissilvestriscatus) enucleated oocytes. Theriogenology66, 275-282.

\section{How to cite this article:}

Sajad A. Beigh, Wani A. Ahad, Rumase A. Bhat, Mehrajuddin Reshi and Riaz A. Shah. 2017. Interspecies Cloning-A Step towards Conservation of Endangered Species: A Review. Int.J.Curr.Microbiol.App.Sci. 6(10): 5035-5038. doi: https://doi.org/10.20546/ijcmas.2017.610.477 